\title{
Exposolidária 2002: a construção de sentido na publicidade
}

Daniele Pereira da silva Universidade Tuiuti do Paraná/UTP - mestranda 


\section{Resumo}

Este ensaio faz a análise da construção de sentido em um anúncio publicitário, empregando a semiótica como instrumento para o estudo da linguagem persuasiva utilizada na publicidade. Para tanto, recorreu-se à divisão entre o plano da expressão e o plano do conteúdo, este abordado em três níveis: fundamental, narrativo e discursivo. Assim, comprovou-se o uso do jogo manipulatório, o qual evidencia o contrato estabelecido entre emissor e receptor acentuando a competência do destinador, em fazer-fazer e também a competência do destinatário, em dever-fazer - levando-o à ação

\section{Palavras-chave}

comunicação, publicidade, semiótica, social

\section{Abstract}

This essay analyses the construction of the meaning in one advertisement, based on the greimasian semiotic theory like an instrument to study persuasive language used in publicity. In order to reach this objective, the analyses was divided into parts: expression and conten.. The approach in this second part causes a division into three levels: basic (fundamental), narrative and discursive. Thus, it was evident the manipulative play, which shows the veridical contract established between emitter and receptor reinforceing the competence of the destinator, to be able to and the competence of the receiver, have to do - taking him to action.

\section{Key words}

communication, advertising, semiotic, social 
tualmente, o terceiro setor da sociedade representado pelas Organizações Não-Governamentais $(\mathrm{ONG})^{\prime}$ é um dos que mais cresce. Observa-se o surgimento de milhares de fundações, institutos e entidades assistenciais, todos com os mesmos objetivos declarados: auxiliar, contribuir, ser solidário.

Grandes empresas investem no social adotando uma entidade ou montando projetos de ação e assumindo uma causa a ser trabalhada. Este conceito de cidadania cresce e se espalha em toda a sociedade. Segundo pesquisa realizada pela ADVB (Associação de Dirigentes de Vendas do Brasil) com 810 empresas de médio e grande portes "investimentos nárea social foram de R\$131,7 milhões em 99 e $79 \%$ das empresas responderam que pretendem ampliar seus projetos para o próximo ano." As pessoas são chamadas a colaborar de alguma maneira: surgem os voluntários, pessoas dispostas a oferecer uma parcela do seu tempo ou a sua mão-de-obra na esperança de um mundo melhor. $\mathrm{O}$ ano de 2001 foi definido pela ONU - Organização das Nações Unidas como o "Ano Internacional do Voluntariado" e com esta delimitação e tantas outras que vêm acontecendo fica evidente a importância deste tipo de ação.

As organizações do chamado terceiro setor buscam ajuda de várias maneiras e atualmente começaram a se estabelecer como marca. Com a entrada do marketing social ${ }^{2}$ em ação apresenta-se uma melhoria ná eficiência de vários projetos, o que leva a propaganda a começar a ser fortemente utilizada como ferramenta que

1. Sociedade civil organizada.

2. Segundo o Social Marketing Institute (2001), marketing social é "o planejamento e a implementaçāo de programas desenvolvidos para gerar a mudança social, usando conceitos do marketing comercial". 
contribui para toda esta renovação, como se pode comprovar pela análise de certos ánúncios publicitários divulgados na mídia.

Un anúncio publicitário, como se sabe, tem como objetivo influenciar, persuadir e estimular determinado público a adquirir certo produto ou serviço; também podendo trabalhar com a divulgação de uma idéia ou de um novo conceito. $\mathrm{O}$ interesse é gerado à medida em que a mensagem informa o valor do produto demonstrando seus benefícios, despertando o desejo e, consequientemente, levando o consumidor à aquisição daquilo que foi anunciado. No caso em que se trabalha a divulgação de uma idéia, então, procura-se influenciar o público esperando uma mudança de atitude do mesmo. A mensagem é elaborada com uma linguagem pretensamente adequada ao destinatário, contendo diversos sistemas de representação que visam a influenciá-lo. Assim, o anúncio contribuíra para o retorno esperado desta forma de comunicação. Pode-se dizer que o objetivo da divulgação foi alcançado quando as metas estabelecidas pelo anunciante cumpriram-se.

\section{Anúncio publicitário: "Exposolidária 2002"}

O anúncio analisado é da feira "Exposolidária 2002", que aconteceu de 2 a 1 I de agosto no Pavilhão da Bienal-SP, ele foi elaborado pela agência DPZ e veiculado nas principais revistas de interesse geral em circulação (Veja, Isto é, Época). Os objetivos desta divulgação são facilmente reconhecíveis: atrair pessoas para a visitação da feira, conquistar o engajamento do leitor através do anúncio, promover empatia do público com a proposta apresentada. Mas o processo que leva a esta primeira "leitura" é um pouco mais complexo.

Através do esquema canônico da comunicação, pode-se identificar os elementos que compõem o referido processo. A empresa organizadora da feira, através de sua agência de publicidade, ocupa o papel de destinador: já o destinatário é o público para o qual a mensagem (anúncio, representação, objeto da comunicação) é elaborada; o canal utilizado é o meio impresso - revista; o contexto é a realidade onde todos estão inseridos.

Iniciando-se a análise pelo plano da expressão notam-se os seguintes elementos: foto, texto 1 (entre aspas), texto 2, slogan e 
logomarca. A diagramação deste anúncio é muito interessante, pois é através dela que a mensagem é compreendida e consegue-se o efeito de sentido desejado, a ruptura.

A escolha de página dupla favorece a montagem da idéia. A foto do rosto da moça com um chapéu em close na página da esquerda e também, o ângulo escolhido e a expressão facial da modelo, são algumas características que juntas geram um sentido que depois é quebrado com o texto 2 .

O cromatismo predominante é o sépia, que confere uma coloração escura à peça. A falta do colorido traduz a seriedade do assunto tratado e também a tristeza, a dor e o sofrimento do doente. A única cor em destaque é o azul da logomarca no canto inferior direito da página, fazendo alusão à harmonia e à tranqüilidade.

A logomarca é o desenho de uma mão, ou melhor, é a personificação da mão que ganha olhos, boca, braços, pernas e expressão. Tudo isto se relaciona ao fato do trabalho voluntário, da ajuda, do "dar a mão" ao próximo.

Na composição da peça, o fato de os elementos estarem em sua disposição, distantes, espalhados e estar sobrando espaço vazio traz a tona uma realidade vivida, muitas vezes, por pessoas vítimas do câncer: o isolamento, o preconceito, a solidão.

Já no plano do conteúdo, abordado neste estudo em três níveis, pode-se identificar outros elementos que contribuem fortemente para o entendimento do percurso gerativo de sentido apresentado neste anúncio.

No nível primário, também chamado de nível das estruturas fundamentais, encontram-se as seguintes oposições semânticas:

\begin{tabular}{|l|c|l|l|}
\hline \multicolumn{1}{|c|}{ Positivas ou Eutóricas } & versus & \multicolumn{1}{|c|}{ Negativas ou Disfóticas } \\
\hline vida - saúde, vitalidade & is & morte - doença, câncer \\
\hline $\begin{array}{l}\text { vencer - ganhar, triunfar, superar a } \\
\text { doença }\end{array}$ & is & $\begin{array}{l}\text { perder - destruir, ser derrotado } \\
\text { pela doença }\end{array}$ \\
\hline $\begin{array}{l}\text { entusiasmo - participar, ajudar, ser } \\
\text { voluntário, ser solidário, engajar-se }\end{array}$ & is & $\begin{array}{l}\text { indiferença - ignorar, nào } \\
\text { participar }\end{array}$ \\
\hline $\begin{array}{l}\text { sucesso - cumprir com as suas } \\
\text { obrigaçòes, fazer a sua parte }\end{array}$ & is & $\begin{array}{l}\text { fracasso - nào ajudar, } \\
\text { desconhecer }\end{array}$ \\
\hline
\end{tabular}




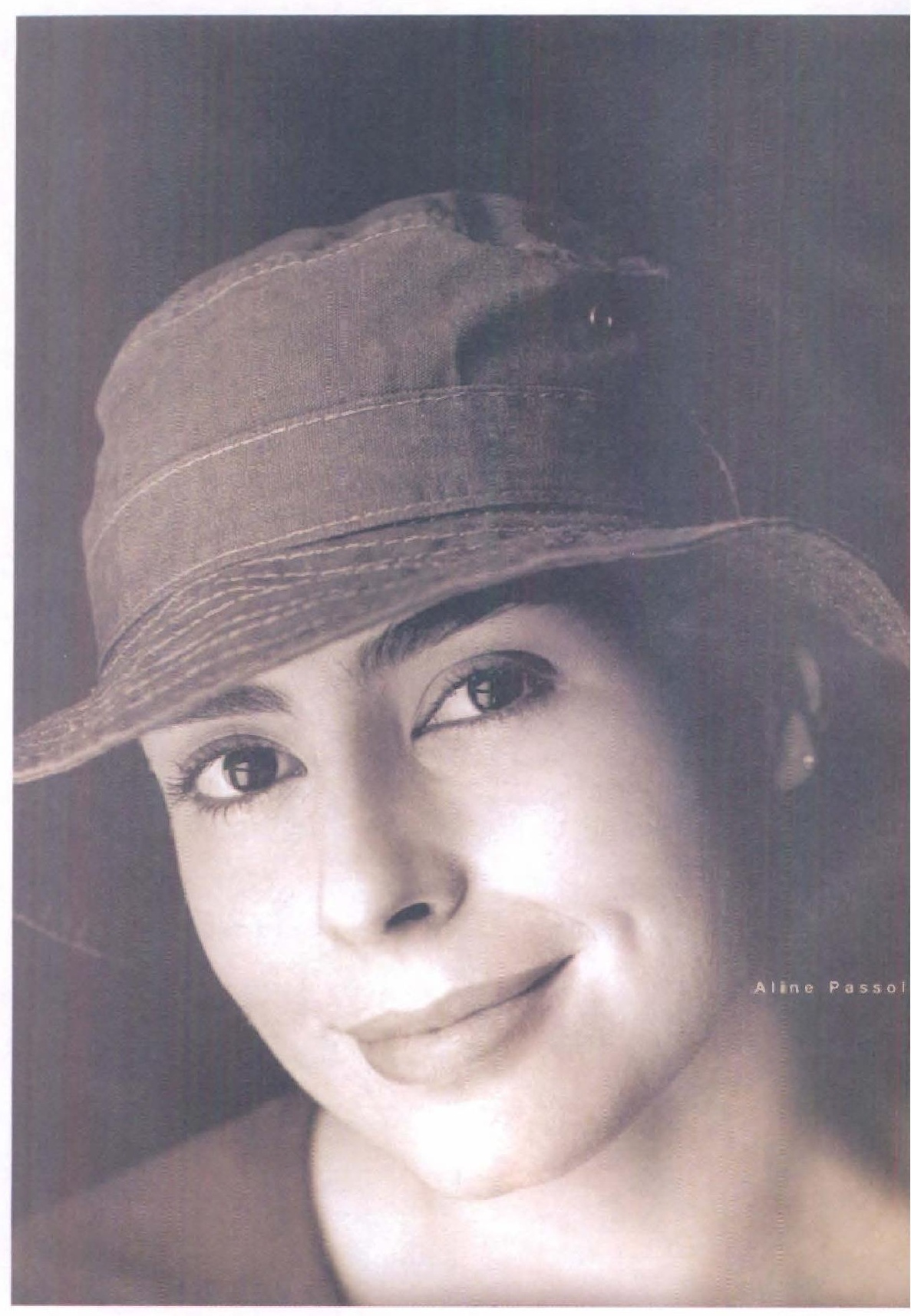


(1)

Conviver 5 encs $32 \mathrm{~m}$ o càncer

$m e f \in z$ acreditar na -ica.

E 0 melho:i $\quad$ e ajudou a romper

mintas proprias baseiras.

a solreu dessa doenca- Ela esta falando do seu trabatho yoluctário.

sina a Exposalidária 2002 e conhoca o trabalho das principais instituiçós da 3 setor.

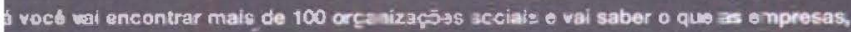
culdades e universidados estäo faserso pare ajklar. 1530 som falar na mostrs cultural a loja soliddria e na biblioteca exclleva de $3^{P}$ 3etor. A feira ainda vai dacicar um dia

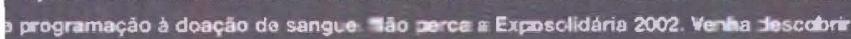
que vosê também pode fazer para zudar.

e 2 a 11 de agosto no Pedilhão ca Bienal. andartiomillonato org br

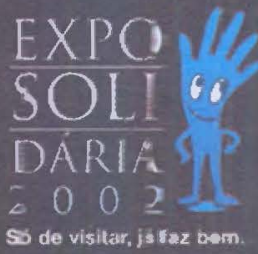




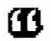

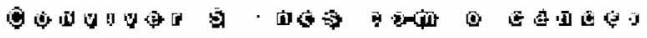

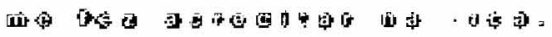

回

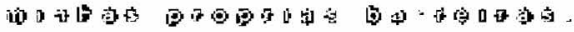

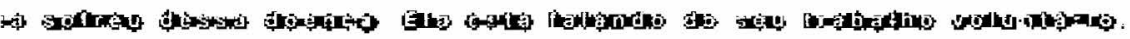

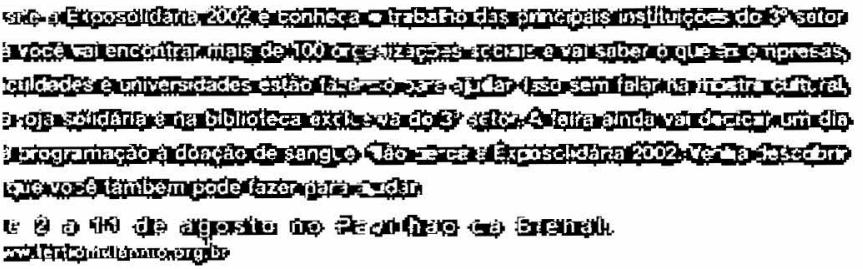


Essas manifestações são evidentes no texto verbal:

"Conviver 5 anos com o câncer me fez acreditar na vida" (vida vs morte; ganhar vs perder);

"Venha descobrir o que você também pode fazer para ajudar" (entusiasmo vs indiferença);

"me ajudou a romper minhas próprias barreiras" (sucesso vs fracasso).

As relações mencionadas estabelecem um percurso entre os termos citados, uma vez que não se concebe a morte sem pressupor a vida.

Já em um nível secundário ou das estruturas narrativas, esses valores em oposição semântica são assumidos como valores pelo sujeito da narrativa que através de sua ação gera mudanças de estado, transformação. Na Semiótica greimasiana, de acordo com Barros (1997, p. 16) "as estruturas narrativas simulam tanto a história do homem em busca de valores ou à procura de sentido quanto a dos contratos e dos conflitos que marcam os relacionamentos humanos".

A peça publicitária em análise relata o testemunho, o depoimento, a declaração de uma vítima do câncer. Desse modo, o destinador através de um jogo de manipulação ${ }^{3}$ por intimidação atinge o destina-ário em seu ponto fraco. Ele utiliza sua competência de destinador-manipulador ("poder": valores negativos) - depoimento de uma pessoa doente, sofrimento - para ocasionar uma alteração na competência do destinatário ("dever-fazer") - ajudar, colaborar, fazer a sua parte. O destinatário se sente intimidado, assustado com o simulacro de realidade que o anúncio consegue construir através da junção da foto e do depoimento.

No entanto, logo abaixo se observa um outro texto que provoca uma ruptura na expectativa criada no início do anúncio, ou melhor, ro contrato veridictório estabelecido entre destinador e destinatário. Pois, de acordo com estudos da modalização do ser, o pa-

3. Segunco Greimas, "a manipulaçāo caracieriza-se como uma ação do homem sobre outros homens, visando a fazê-los executar um programa dado" (1979, p.269). 
recer é trocado pelo não-ser, a moça parecia que tinha câncer e depois fica evidente que não (mentira). Isso acontece devido ao conteúdo implícito do primeiro texto que leva o destinatário a pressupor algo que, depois, é negado. Através desta complementação, o discurso ganha outro sentido e o contexto geral também é modificado. A idéia da doença, do sofrimento, apresentada anteriormente é deixada de lado e surge uma nova perspectiva desta situação: a solidariedade, o trabalho voluntário.

$\mathrm{O}$ anúncio apresenta uma estrutura narrativa que estimula um desejo e uma vontade de ter e/ou de ser algo. O que conduz o consumidor à ação nesta peça é o benefício que a aquisição do produto ocasionará. No caso, a simples participação na feira promete proporcionar um bem-estar ao leitor que estará certo de cumprir com as suas obrigaçōes fazendo a sua parte, como o próprio slogan diz: "Só de visitar, já faz bem".

Nesta última etapa do percurso gerativo do sentido, nível do discurso, as estruturas discursivas devem ser examinadas do ponto de vista das relações que se instauram entre a instância da enunciação e do texto enunciado. Segundo Barros (1997, p.62),

o enunciador define-se como o destinador-manipulador responsável pelos valores do discurso e capaz de levar o enunciatário a crer e a fazer. A manipulação do enunciador exerce-se como um fazer persuasivo, enquanto ao enunciatário cabe o fazer interpretativo e a ação subsequiente.

Pode-se observar algumas marcas deixadas no texto 1) o uso das aspas, o discurso direto, ou seja, em primeira pessoa, tudo isto para criar um efeito de sentido de subjetividade na visão dos fatos vividos e narrados por quem os viveu. A performance do sujeito, a moça, em busca de um objeto, a cura, pressupõe a aquisição de competência para realizar a ação, precisando para tanto da ajuda de outras pessoas. Tal estratégia provoca no leitor, no papel de enunciatário, um sentimento de compaixão, de solidariedade para com o sofrimento alheio. Logo adiante, ocorre a ruptura do contrato 
estabelecido entre enunciador e enunciatário, o discurso torna-se indireto, em terceira pessoa, instituindo o efeito de sentido de objetividade. Ao citar o nome da moça, Aline Passolargo. concretiZá-se no anúncio o autor do discurso jogando com a identidade pública da atriz e observa-se um efeito de sentido de realidade. A princípio, antes desta revelação inesperada, o enunciatário fora levado a pensar que a moça estava com câncer, agora o discurso esclarece que o que o enunciador estava querendo dizer é somente que ela trabalha como voluntária nesta área e não é portadora da doença.

O papel da fotografia, neste anúncio, é de ancoragem, assegurado pelá crença ideológico-cultural do seu caráter analógico de "cópia do real", fortalecendo o efeito de realidade. A foto (mulher com um chapéu) faz acreditar que ela está careca devido às conseqüências do tratamento da doença (quimioterapia), pois não mostra o cabelo, reforçando a construção de um clima que desperta no enunciatário uma reação, um espanto. A escolha da imagem de uma figura feminina explora a crença de que a mulher se deixa levar mais pelo zoração, pela emoção. Além disso, atribuir-se-ia um grau de vaidade superior ao universo feminino e assim a falta de cabelo para este gênero seria muito mais prejudicial e traumatizante do que para o sexo masculino. O fator que faz o anúncio ganhar forças é o preconceito: mulher careca não é nada comum e isso provoca isolamento da sociedade e até solidão. Sem contar com a perda da elegância, do charme, da sensualidade que os cabelos conferiam à mulher. Diante destes fatores que convocam o contexto social ao qual a personagem do anúncio e o público fazem parte, pode-se dizer que um dos objetivos do anúncio é provocar surpresa, abalo, choque e comoção.

O slogan. "Só de visitar, já fáz bem" promete uma recompensa para o cumprimento da ação indicada no enunciado. Tanto a persuasão do enunciador quanto a interpretação do enunciatário da propaganda se realizam no e pelo discurso publicitário. E maior será a eficácia se o enunciador e enunciatário-consumidor partilharem da mesma formação discursiva, defïnida por Fiorin (1989) como "um conj-anto de temas e de figuras que materializa uma dada visão de mundo". O mecanismo é simples: o discurso parecerá mais ver- 
dadeiro quanto mais o destinatário identificar e conseguir comprovar, por meio das performances apresentadas em forma de simulacro, suas convicções e verdades íntimas.

\section{Considerações finais}

A premissa de que a comunicação acontece por meio de sistemas de signos, num jogo de negociação, é verificada no estudo desta peça publicitária. Com a aplicação da teoria semiótica do texto para a análise da mesma, vários elementos importantes, por vezes obscuros, desconhecidos ou até despercebidos, foram revelados e puderam ser compreendidos.

As representações relacionadas justificam o conceito e o posicionamento expressos na peça. Cada elemento contribui para a construção da imagem desejada pelo anunciante. A divisão entre o plano da expressão e o plano do conteúdo facilita e muito a compreensão do texto e, particularmente, de todas as estruturas que o compõe.

A estratégia construtiva do anúncio é bem interessante, para uma leitura superficial o que chama a atenção é o contraste entre a doença e a jovem-bonita, posteriormente ocorre um deslocamento para abordar a solidariedade provocando uma identificação e uma empatia com o leitor e, finalmente, apresenta a feira e propõe a participação no evento con um convite.

O jogo da intimidação encontra nesta peça subsídios textuais que contribuem para os efeitos de sentido desejados. Dois fatores merecem destaque: o fazer persuasivo do destinador que, utilizando um sistema de códigos comuns aos actantes desta relação comunicacional, direciona e manipula o destinatário; e a ponte enunciação-enunciado, que possibilita a percepção não só do que está explícito, mas também o que sugerem as marcas deixadas no texto. 


\section{Bibliografia}

ARNHEIM, R. 2000. Arte e percep̧̧ão visual. São Paulo: Pioneira, EDUSP?

BARROS. D. L. P. 1988. Teoria do discurso: fundamentos semióticos. São Paulo: Atual.

BARROS. D. L. P. 1990. Teoria semiótica do texto. São Paulo: Ática.

CARVALHO, N. 1996. Publicidade: a linguagem da sedução. São Paulo: Ed. Ática.

FIORIN. J. L. 1989. Elementos de análise do discurso. São Paulo: Contexto/EDUSP.

GReimas, A.J. \& COURTÉS, J. 1979. Dicionário de Semiótica. São Paulo: Cultrix.

JOLY, M. 1996. Introdução à análise da imagem. Campinas. SP: Papirus Editora.

ORLANDi, E. P. 2000. Análise de discurso. Campinas, SP: Pontes.

SANT"ANNA. A. 2002. Propaganda: teoria, técnica e prática. São Paulo: Pioneira Thomson Learning.

VESTERGAARD, T. \& SCHROEDER. K. 1998. A linguagem da propacada. São Paulo: Martins Fontes. 